\title{
Burnout among ENT Residents During Covid-19 Pandemic: What are the Contributing Factors?
}

Andrey Dwi Anandya ${ }^{1 *}$, Abla Ghanie ${ }^{1}$, Ahmad Hifni ${ }^{1}$

${ }^{1}$ Department of Otorhinolaryngology, Faculty of Medicine, Universitas Sriwijaya, Palembang, Indonesia

*Corresponding author:

Andrey Dwi Anandya

Department of Otorhinolaryngology, Faculty of Medicine, Universitas

Sriwijaya, Palembang, Indonesia

Email:

adanandya@gmail.com

https://doi.org/10.37275/jacr.v2i2.165

\begin{abstract}
Introduction. Resident doctors are susceptible to burnout syndrome, which is the combination of physical and psychological fatigue, that may affect their performance. Long-term pandemic of Covid-19 may also contribute to increasing the severity of burnout among residents doctor, might be because the increasing of work time and effort to treat the patients during the time while maintaining prevention against the possible exposure that may harm themselves. This study was aimed to evaluate burnout prevalence among ENT (Ear-Nose-Throat) medical residents in Covid-19 pandemic, and its relation to certain factors of demographic and wellness.

Methods. Thirty ENT medical residents of Medical Faculty of Sriwijaya University were enrolled as the study population. Burnout was measured by Copenhagen Burnout Inventory (CBI) and divided by three parameters (personal,work-related, patient-related).

Results. Among 30 ENT resident doctors at Rumah Sakit Moh. Hoesin, the mean level of personal burnout was 53.056 (SD 17.125), work-related burnout was 47.975 (SD 17.663), and patient-related burnout was 34.861 (SD 20.746).

Conclusion. Marriage, female gender, and inadequacy of PPE may contribute to the development of burnout. The burnout among resident doctors is a serious matter regarding their role as a frontline doctor during the pandemic era, because it may affect not only their performance at work, but toward their life as well.
\end{abstract}

Keywords: burnout, resident doctors, covid-19 pandemic, medical staff, psychiatry. 


\section{Introduction}

Covid-19 is a pandemic caused by SARS-CoV-2 (Severe Acute Respiratory Syndrome Coronavirus 2), with symptoms ranged from asymptomatic, that may lead to underdiagnosed, to life threatening. The disease spread via contaminated droplet from infected individual, and aerosol, that may contact to the mucosal surface of other people. The droplet will travel over longer distance if the patients are coughing or sneezing, and the viral particle may last longer in the air inside indoor environment. Preventive measures are essential to avoid contact with SARS-CoV-2, including social distancing, wearing face mask properly, frequent hand washing, covering mouth while coughing or sneezing, cleaning the surface, and good

ventilation. ${ }^{1}$ Nowadays, there are several variants of SARS-Cov-2 that considered more virulent, like Alpha, Beta, and Delta variants. Covid-19 became 8th most deadly pandemic in history with reported of 4.3 million death worldwide. ${ }^{2,3}$ Covid-19 also hit an impact on economic and social sector, including healthcare. Increasing workload, worktime, and limited number of PPE (Personal Protective Equipment), medication, and medical instruments may contribute to an increasing stress among physicians, or other medical staff, that keep struggling to battle against Covid-19 while maintaining to protect themselves from potential exposure of the infection. ${ }^{4,5}$

Stress is a response to a stressor by an organism. Stressor can be divided into biological, physiological, and psychological and certain response will be triggered to cope with the exposure of those stimuli. In human, autonomic nervous system, through SAM (Sympathoadrenal Medullary) axis and HPA (Hypothalamic Pituitary Adrenal) axis are responsible for stress mechanism. ${ }^{6}$ Stress may alter immune function, metabolism, memory, and even individual performance in certain job. The latter is usually due to chronic occupational stress that may lead to burnout. ${ }^{7,8}$ The study about burnout itself dated back to $1970 \mathrm{~s}$ when subjects, most were industrial workers, was showing psychososial problem due to occupational stress. Nowadays, observation toward burnout is not only limited to industrial laborers, but also every sector workers, including healthcare physician. ${ }^{9}$ There are several instruments that can be applied to quantify burnout on certain group of individuals, like MBI (Maslach Burnout Inventory), BM (Burnout Measure) questionnaire, OBI (Oldenburg Burnout Inventory), PHQ-9 (Patient Health Questionnaire-9), and CBI (Copenhagen Burnout Inventory).

Medical residents are one of the front line health care personnel facing against Covid-19 and may susceptible to burnout syndrome. There are lot of studies about burnout among healthcare personnel, especially medical residents. However, there are fewer numbers of studies about burnout in this era of 


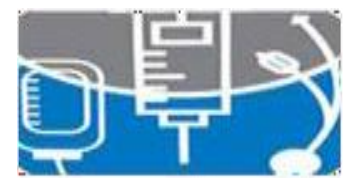

\section{Journal of Anesthesiology \& \\ Clinical Research}

pandemic. ${ }^{10,11}$ This study was designed to find out the burnout prevalence among ENT medical residents in Covid-19 pandemic, and its relation to certain factors of demographic and wellness.

\section{Methods}

Thirty ENT medical residents of Medical Faculty of Sriwijaya University were enrolled as the study population. They were working at Rumah Sakit Mohammad Hoesin in Palembang as the main affiliation hospital. The study was conducted from June to August 2021. Anonymous electronic questionnaires were distributed among subjects through a link to Google ${ }^{\circledR}$ form. Any incomplete response of questionnaire were excluded from the study. Sociodemographic data and burnout status were collected cross sectionally and analyzed using IBM SPSS® ver. 24.

CBI scale was used to measure the prevalence of burnout among subjects. CBI scale was reliable and validated, and also free access, which consists of 19 items questionnaire that divided into three

subscales. ${ }^{9,12,13}$ Each of the item was measured in numerical value, based on their answer (Always / To a very high degree $=100 ;$ Often $/$ To a high degree $=75$; Sometimes $/$ Somewhat $=50 ;$ Seldom $/$ To a low degree $=25$; Never $/$ Almost never $/$ To a very low degree $=0$ ). Personal burnout, the most generic, describes a state of prolonged physical and psychological exhaustion and consists of 6 items. Work-related burnout, consists of 7 items, describing the state of prolonged physical and psychological exhaustion, which is perceived as related to the individual work. Client-related burnout, consists of 6 items, describing the state of prolonged physical and psychological exhaustion, which is perceived as related to the individual work with clients. ${ }^{9}$ The word "clients" in the latter subscales was changed into "patients" to address the specific clients of the subjects line of work. Total score was calculated based on each subscales. The score below 50 was considered low, 50-74 was considered moderate, 75-99 was considered high, and a total score of 100 was considered severe burnout. ${ }^{9,14}$

\section{Results}

From the total of 30 medical residents, 11 (36.7\%) were males and $19(63.3 \%)$ were females. The mean age of participants was $32.6( \pm 2.59)$ years old. Table 1 shows that most of the residents were at senior level $(70 \%)$, married (80\%), and come from Palembang (80\%). While the demographic data related to Covid-19 from the same table shows that the majority of them never get Covid-19 infection (66.7\%), did not contracted the disease when the data was collected (90\%), and did not have family members that had Covid-19 infection. Symptoms were found in the majority of the residents that had Covid-19 infection 


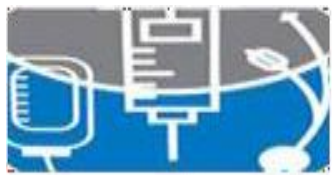

\section{Journal of Anesthesiology\& \\ Clinical Research}

(90\%). The working duration was decreased $(48.333 \pm 25.54 \mathrm{~h})$ compared to the time before Covid-19 pandemic happened $(50.167 \pm 15.946 \mathrm{~h})$ and there were $2(6.7 \%)$ responses from participants regarding the limitation of PPE while working at the hospital. All of the residents already got Covid-19 vaccination $(100 \%)$.

Table 1. Demographic data of participants

\begin{tabular}{|c|c|c|}
\hline Demographic & Frequency & Percentage (\%) \\
\hline $\begin{array}{c}\text { Gender } \\
\\
\\
\text { Female } \\
\text { Female }\end{array}$ & $\begin{array}{l}11 \\
19 \\
\end{array}$ & $\begin{array}{l}36.7 \\
63.3\end{array}$ \\
\hline $\begin{array}{r}\text { Level of Residents } \\
\text { Junior } \\
\text { Middle } \\
\text { Senior }\end{array}$ & $\begin{array}{c}4 \\
5 \\
21 \\
\end{array}$ & $\begin{array}{c}13.3 \\
16.7 \\
70 \\
\end{array}$ \\
\hline $\begin{array}{l}\text { Background } \\
\text { Palembang } \\
\text { Not from Palembang }\end{array}$ & $\begin{array}{l}17 \\
13 \\
\end{array}$ & $\begin{array}{l}56.7 \\
43.3 \\
\end{array}$ \\
\hline $\begin{array}{c}\text { Marital Status } \\
\text { Married } \\
\text { Not Married } \\
\end{array}$ & $\begin{array}{c}24 \\
6 \\
\end{array}$ & $\begin{array}{l}80 \\
20 \\
\end{array}$ \\
\hline $\begin{array}{c}\text { History of Covid-19 infection } \\
\text { Yes } \\
\text { No }\end{array}$ & $\begin{array}{l}10 \\
20\end{array}$ & $\begin{array}{l}33.3 \\
66.7\end{array}$ \\
\hline $\begin{array}{c}\text { Currently infected by Covid-19 } \\
\text { Yes } \\
\text { No }\end{array}$ & $\begin{array}{c}3 \\
27\end{array}$ & $\begin{array}{l}10 \\
90\end{array}$ \\
\hline $\begin{array}{l}\text { Symptoms while infected by Covid- } \\
19 \begin{array}{l}\text { Yes } \\
\text { No / Never get infection }\end{array}\end{array}$ & $\begin{array}{c}9 \\
21\end{array}$ & $\begin{array}{l}30 \\
70\end{array}$ \\
\hline $\begin{array}{l}\text { Covid-19 vaccination } \\
\text { Already get shot } \\
\text { Never get shot }\end{array}$ & $\begin{array}{c}30 \\
0 \\
\end{array}$ & $\begin{array}{c}100 \\
0 \\
\end{array}$ \\
\hline $\begin{aligned} & \text { PPE limitation } \\
& \text { Yes } \\
& \text { No } \\
&\end{aligned}$ & $\begin{array}{c}28 \\
2 \\
\end{array}$ & $\begin{array}{c}93.3 \\
6.7\end{array}$ \\
\hline $\begin{array}{c}\text { Working duration }(\mathrm{h}) \\
\text { Before Pandemic } \\
\text { In Pandemic } \\
\end{array}$ & $\begin{array}{c}\text { Mean } \\
50.167 \\
48.333 \\
\end{array}$ & $\begin{array}{c}\mathrm{SD} \\
15.946 \\
25.54 \\
\end{array}$ \\
\hline $\begin{array}{l}\text { Working duration } \\
\text { Increase } \\
\text { Decrease } \\
\text { No Change }\end{array}$ & $\begin{array}{c}2 \\
15 \\
13\end{array}$ & $\begin{array}{c}6.7 \\
50 \\
43.3\end{array}$ \\
\hline $\begin{array}{l}\text { Family members get infected by } \\
\text { Covid-19 } \\
\text { Yes } \\
\text { No }\end{array}$ & $\begin{array}{l}14 \\
16\end{array}$ & $\begin{array}{l}46.7 \\
53.3\end{array}$ \\
\hline
\end{tabular}


Of the 30 participants had low total burnout $(45.298 \pm 15.685)$, with moderate personal burnout $(53.056 \pm 17.125)$, low work-related $(47.975 \pm 17.663)$ and client-related $(34.861 \pm 20.746)$ burnout. Burnout score can be seen on Table 2.

Table 2. Burnout score of participants

\begin{tabular}{|c|c|c|}
\hline CBI Subscales & Score (Mean) & $\mathbf{\pm S D}$ \\
\hline Personal burnout & 53.056 & 17.125 \\
Work-related burnout & 47.975 & 17.663 \\
Client-related burnout & 34.861 & 20.746 \\
\hline Total burnout & 45.298 & 15.685 \\
\hline
\end{tabular}

Unfortunately, the majority of demographic factors did not have a significant value related to burnout subscales (Table 3). Only marital status showed a clinically difference and statistically significant value to client-related burnout $(37.487 \pm 21.837$ vs $22.915 \pm 9.411, p=0.02)$. Predictors of personal burnout and patient-related burnout can be seen in Table 4 and Table 5.

Table 3. Demographic related to burnout subscales

\begin{tabular}{|c|c|c|}
\hline Factors & $\begin{array}{c}\text { Burnout Score } \\
\text { (Mean / Median) }\end{array}$ & $\boldsymbol{p}$ value \\
\hline Sex & & \\
Personal burnout & $54.17(25-100)$ & 0.812 \\
Male & $58.33(12.5-66.67)$ & \\
Female & $46.105( \pm 17.6)$ & 0.667 \\
Work-related burnout & $49.059( \pm 18.088)$ & \\
Female & $31.44( \pm 17.908)$ & 0.502 \\
Client-related burnout & $36.841( \pm 22.449)$ & \\
Male & Pearson's r & 0.935 \\
Female & 0.016 & 0.969 \\
Age & 0.135 & 0.478 \\
\hline $\begin{array}{c}\text { Personal burnout } \\
\text { Work-related burnout }\end{array}$ & \\
Client-related burnout & $62.5(54.17-75)$ & \\
\hline Level of Resident & $62.5(25-100)$ & 0.267 \\
Personal burnout & $54.17(12.5-66.67)$ & \\
Junior & & \\
Middle & & \\
Senior & & \\
\hline
\end{tabular}




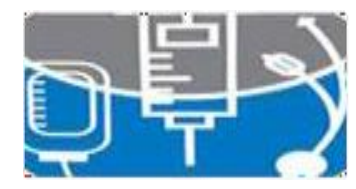

Journal of Anesthesiology \&
Clinfical Research

\begin{tabular}{|c|c|c|}
\hline $\begin{array}{r}\text { Junior } \\
\text { Middle } \\
\text { Senior } \\
\text { Client-related burnout } \\
\text { Junior } \\
\text { Middle } \\
\text { Senior }\end{array}$ & $\begin{array}{c}59.82( \pm 14.688) \\
50.714( \pm 20.421) \\
45.067( \pm 17.257) \\
\\
39.583( \pm 17.178) \\
35( \pm 18.064) \\
33.928( \pm 22.564)\end{array}$ & 0.298 \\
\hline $\begin{array}{c}\text { Background } \\
\text { Personal burnout } \\
\text { Palembang } \\
\text { Not from Palembang } \\
\text { Work-related burnout } \\
\text { Palembang } \\
\text { Not from Palembang } \\
\text { Client-related burnout } \\
\text { Palembang } \\
\text { Not from Palembang }\end{array}$ & $\begin{array}{l}54.902( \pm 20.636) \\
50.641( \pm 11.392) \\
49.158( \pm 20.691) \\
46.429( \pm 13.363) \\
35.784( \pm 21.703) \\
33.654( \pm 20.231)\end{array}$ & 0.682 \\
\hline $\begin{array}{c}\text { Marital status } \\
\text { Personal burnout } \\
\text { Married } \\
\text { Not married } \\
\text { Work-related burnout } \\
\text { Married } \\
\text { Not Married } \\
\text { Client-related burnout } \\
\text { Married } \\
\text { Not Married } \\
\end{array}$ & $\begin{array}{l}55.903( \pm 15.293) \\
41.667( \pm 25.75) \\
49.553( \pm 16.958) \\
41.665( \pm 20.663) \\
37.847( \pm 21.837) \\
22.915( \pm 9.411)\end{array}$ & 0.337 \\
\hline $\begin{array}{r}\text { History of Covid-19 infection } \\
\text { Personal burnout } \\
\text { Yes } \\
\text { No } \\
\text { Work-related burnout } \\
\text { Yes } \\
\text { No } \\
\text { Client-related burnout } \\
\text { Yes } \\
\text { No }\end{array}$ & $\begin{array}{c}53.334( \pm 15.189) \\
52.917( \pm 18.393) \\
46.784( \pm 13.929) \\
48.571( \pm 19.574) \\
30( \pm 19.719) \\
37.291( \pm 21.309)\end{array}$ & $\begin{array}{l}0.799 \\
0.373\end{array}$ \\
\hline $\begin{array}{r}\text { Currently infected by Covid-19 } \\
\text { Personal burnout } \\
\text { Yes } \\
\text { No } \\
\text { Work-related burnout } \\
\text { Yes } \\
\text { No } \\
\text { Client-related burnout } \\
\text { Yes } \\
\text { No }\end{array}$ & $\begin{array}{c}58.333( \pm 4.165) \\
52.469( \pm 17.95) \\
51.19( \pm 5.453) \\
47.618( \pm 18.557) \\
16.67(16.67-58.33) \\
25(0-87.5)\end{array}$ & $\begin{array}{l}0.746 \\
0.463\end{array}$ \\
\hline $\begin{array}{l}\text { Symptoms while infected by Covid-19 } \\
\text { Personal burnout } \\
\text { Yes } \\
\text { No / Never get infection } \\
\text { Work-related burnout } \\
\text { Yes } \\
\text { No / Never get infection } \\
\text { Client-related burnout }\end{array}$ & $\begin{array}{l}55.093( \pm 14.991) \\
52.182( \pm 18.239) \\
48.015( \pm 14.187) \\
47.959( \pm 19.284)\end{array}$ & 0.994 \\
\hline
\end{tabular}




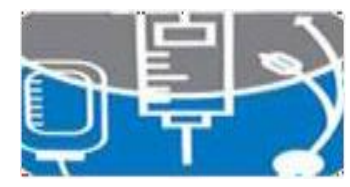

Journal of Anesthestiology \&

Clinical Research

\begin{tabular}{|c|c|c|}
\hline $\begin{array}{c}\text { Yes } \\
\text { No / Never get infection }\end{array}$ & $\begin{array}{l}30.556( \pm 20.832) \\
36.706( \pm 20.942)\end{array}$ & 0.467 \\
\hline $\begin{array}{l}\text { PPE limitation } \\
\text { Personal burnout } \\
\text { Yes } \\
\text { No } \\
\text { Work-related burnout } \\
\text { Yes } \\
\text { No } \\
\text { Client-related burnout } \\
\text { Yes } \\
\text { No }\end{array}$ & $\begin{array}{c}52.084( \pm 14.764) \\
66.665( \pm 47.143) \\
46.938( \pm 16.687) \\
62.5( \pm 32.824) \\
33.333( \pm 20.631) \\
56.25( \pm 2.942)\end{array}$ & 0.134 \\
\hline $\begin{array}{c}\text { Changing in a working hour } \\
\text { Personal burnout } \\
\text { Increase } \\
\text { Decrease } \\
\text { No Change } \\
\text { Work-related burnout } \\
\text { Increase } \\
\text { Decrease } \\
\text { No Change } \\
\text { Client-related burnout } \\
\text { Increase } \\
\text { Decrease } \\
\text { No Change } \\
\end{array}$ & $\begin{array}{c}56.25( \pm 2.942) \\
48.889( \pm 13.126) \\
57.372( \pm 21.528) \\
\\
50( \pm 10.097) \\
44.762( \pm 15.849) \\
51.372( \pm 20.647) \\
\\
41.665( \pm 23.568) \\
34.444( \pm 20.92) \\
34.295( \pm 21.793) \\
\end{array}$ & 0.789 \\
\hline $\begin{array}{r}\text { Family members get infected by } \\
\text { Covid-19 } \\
\text { Personal burnout } \\
\text { Yes } \\
\text { No } \\
\text { Work-related burnout } \\
\text { Yes } \\
\text { No } \\
\text { Client-related burnout } \\
\text { Yes } \\
\text { No }\end{array}$ & $\begin{array}{c}58.33(12.5-75) \\
52.085(25-100) \\
\\
51.019( \pm 17.52) \\
45.312( \pm 17.914) \\
35.119( \pm 24.224) \\
34.634( \pm 17.983)\end{array}$ & 0.387 \\
\hline
\end{tabular}

Table 4. Predictors of personal burnout

\begin{tabular}{|c|c|c|c|c|}
\hline Factors & Coefficient & $\boldsymbol{p}$ value & $\boldsymbol{\beta}$ & $\mathbf{R}^{\mathbf{2} \text { adj }}$ \\
\hline $\begin{array}{c}\text { (Constant) } \\
\text { Married }\end{array}$ & 34.382 & & & 0.154 \\
\hline $\begin{array}{c}\text { No change of } \\
\text { worktime }\end{array}$ & 17.423 & 0.026 & 0.414 & \\
\hline
\end{tabular}


Table 5. Predictors of patient-related burnout

\begin{tabular}{|c|c|c|c|c|}
\hline Factors & Coefficient & $\boldsymbol{p}$ value & $\boldsymbol{\beta}$ & $\mathbf{R}^{\mathbf{2}}$ adj \\
\hline (Constant) & 5.573 & & & 0.189 \\
\hline Female & 17.342 & 0.036 & 0.41 & \\
\hline Married & 20.353 & 0.048 & 0.399 & \\
\hline Inadequate PPE & 30.323 & 0.042 & 0.371 & \\
\hline
\end{tabular}

\section{Discussion}

Our finding shows that the ENT medical residents have a low burnout score, despite the situation of Covid-19 pandemic. This was similar to reported systematic review by Rodrigues et al that ENT medical residents tend to have a low level of burnout compared to the other departments. ${ }^{15}$ However, the review was observing burnout among residents before Covid-19 pandemic happened. The study from Elghazally et al reported a higher level of burnout on residents during Covid-19 pandemic. ${ }^{16}$

Our finding at each dimension of burnout suggests that the participants had a moderate level of personal burnout and a lower level on work-related, even lower score on client-related burnout. The results are quite similar to a study that conducted by Ratnakaran et al that reported the moderate burnout on personal dimensions and low burnout on both work-related and client-related dimensions. ${ }^{17}$ Other studies found that medical residents tend to have the highest score of personal burnout rather than 2 other subscales, despite the burnout level. ${ }^{17-19}$ These findings show us that medical residents have personal physical and psychological exhaustion that did not relate to their work.

We try to find the other factors that may contribute to their burnout status, including their wellness in the middle of Covid-19 pandemic. However, we found that only the marital status of residents is significantly related to their client-related burnout, despite that the burnout score between married and not married are still on the same level of burnout $(<50 \%)$. Although we assume that being married and also working at the hospital may contribute to higher susceptibility of burnout, especially personal burnout, but our findings do not correspond with the majority of reported studies that having a spouse will help to protect a person to easily get burnout, like study by Chan et al that reported 1.4 times higher psychological fatigue on unmarried compared to the married physician during SARS outbreak in $2003 .{ }^{20}$

Female gender, marriage, and inadequacy of PPE are predictors to patient-related burnout. A study by Peckham et al also reports similar findings that female physicians from all specialties tend to have more 


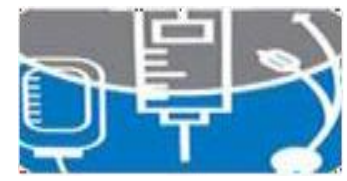

\section{Journal of Anesthestology \& \\ Clinical Research}

burnout than their male colleagues. One of the factors that may contribute to this issue is because female physician tend to become victims of sexual harassment, directly or indirectly, both from their colleagues and patients and this may lead to disrupting their confidence in the workplace and even their career. ${ }^{21,22}$

Treating patients in the pandemic, especially the positively diagnosed by Covid-19, is essentially required of proper PPE to protect physicians. This factor becomes a reason why the inadequacy of PPE may contribute to development of burnout, because of their worriness toward the exposure of such deadly disease. The similar result was reported by Morgantini et al that PPE may have a role as a protector against burnout $(\mathrm{RR}=0.88, p=0.01) .{ }^{23}$

One of the drawback of our study is the design, that our study is unicenter. Therefore, this cannot describe the general population of burnout among ENT residents in our country. And there was no data regarding burnout before Covid-19 pandemic happened. However, it provide an outlook regarding the low burnout level on ENT medical residents. We can assume that maybe work in Covid-19 pandemic was being set properly, regarding the decreasing time of work or total patients that are being treated at ENT departments. Those became another lackness of our study that we did not specifically describe about work load, such as total patients, surgeries, case variety that were faced by ENT residents during the pandemic time. Future studies such as multicenter studies should be designed and carried out to find out more accurate results of burnout among residents.

\section{Conclusion}

The prevalence of burnout among residents cannot be underestimated. Exhaustion due to burnout syndrome may lead to disruption of their work toward the patients and also their personal life. Frequently check up regarding burnout may help to find out burnout symptoms earlier so it could be treated by stress management as soon as possible.

\section{References}

1. Fu L, Nielsen PV, Wang Y, Liu L. Measuring interpersonal transmission of expiratory droplet nuclei in close proximity. Indoor Built Environ. 2021 Jun; 0(0): 1-13

2. Sanyaolu A, Okorie C, Marinkovic A, Haider N, Abbasi AF, Jaferi U et al. The emerging SARSCoV-2 variants of concern. Ther Adv Infectious Dis. 2021 Mar; 8: 1-10

3. John Hopkins Univeristy: Covid-19 Dashboard by the Center for Systems Science and Engineering

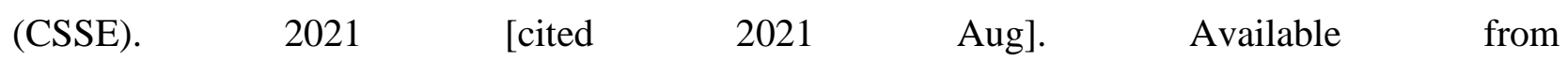




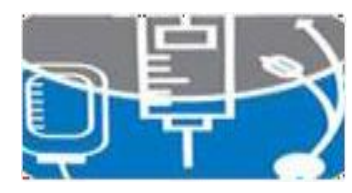

\section{Journal of Anesthesiology \&
Clinical Research}

https://gisanddata.maps.arcgis.com/apps/opsdashboard/index.html\#/bda7594740fd40299423467b $\underline{48 \mathrm{e} 9 \mathrm{ecf} 6}$

4. Pai N, Vella SL. Covid-19 and loneliness: A rapid systematic review. Aust NZJ Psychiatry. 2021; 00(0): 1-13

5. Zoumpourlis V, Goulielmaki M, Rizos E, Baliou S, Spandidos DA. The Covid-19 pandemic as a scientific and social challenge in the 21st century. Mol Med Rep. 2020 Oct; 22(4):3035-48

6. Lai YMU, Herman JP. Neural regulation of endocrine and autonomic stress response. Nat Rev Neurosci. 2009 Jun; 10(6): 397-409

7. Stephens MAC, Wand G. Stress and the HPA axis: Role of glucocorticoid in alcohol dependence. Alcohol Res Health. 2012 Jan. 34(4): 468-83

8. WHO: Burn-out an "occupational phenomenon": International Classification of Diseases. 2019 [cited 2021 Aug]. Available from https://www.who.int/news/item/28-05-2019-burn-out-anoccupational-phenomenon-international-classification-of-diseases

9. Kristensen TS, Borritz M, Villadsen E, Christensen KB. The Copenhagen Burnout Inventory: A new tool for the assessment of burnout. Work and Stress. 2005 Jul. 19(3): 192-207

10. Putri IA, Soedibyo S. Tingkat depresi peserta program pendidikan dokter spesialis ilmu kesehatan anak FKUI-RSCM dan faktor-faktor yang terkait. Sari Pediatri. 2011 Jun; 13(1):70-8

11. Sunjaya DK, Herawati DMD, Siregar AYM. Depressive, anxiety, and burnout symptoms on health care personnel at a month after Covid-19 outbreak in Indonesia. BMC Public Health. 2021 Jan; 21: 227

12. Sestili C, Scalingi S, Cianfanelli S, Mannocci A, Del Cimmuto A, De Sio A et al. Reliability an use of Copenhagen Burnout Inventory in Italian Sample of Univeristy Professors. Int J Environ Res Public Health. 2018; 15: 1708

13. Piperac P, Todorovic J, Terzic-Supic Z, Maksimovic A, Karic S, Pilipovic F et al. The validity and reliability of the Copenhagen Burnout Inventory for examination of burnout among preschool teachers in Serbia. Int J Environ Res Public Health. 2021; 18: 6805

14. Creedy DK, Sidebotham J, Gamble J, Pallant J, Fenwick J. Prevalence of burnout, depression, anxiety and stress in Australian midwives: A cross sectional study. BMC Pregnancy and Childbirth. 2017 Jan; 17:13

15. Rodrigues H, Cobucci R, Oliveira A, Cabral JV, Medeiros L, Gurgel K et al. Burnout syndrome among medical residents: A systematic review and meta-analysis. PloS One. 2018 Nov; 13(11) 


\section{Journal of Anesthesiology \& \\ Clinical Research}

16. Elghazally SA, Alkarn AF, Elkhayat H, Ibrahim AK, Elkhayat MR. Burnout impact of Covid-19 pandemic on health-care personnel at Assiut University Hospitals, 2020. Int J Environ Res Public Health. 2021 May; 18(10): 5368

17. Ratnakaran B, Prabhakaran A, Karunakaran V. Prevalence of burnout and its correlates among residency in tertiary medical center in Kerala, India: A cross-sectional study. J Postgrad Med. 2016 Jul. 62(3): 157-61

18. Nimer A, Naser S, Sultan N, Alasad RS, Rabadi A, Abu-Jubba M et al. Burnout syndrome during residency training in Jordan: Prevalence, risk factors, and implications. Int J Environ Res Public Health. 2021; 18:1557

19. Dhusia AH, Dhaimade PA, Jain AA, Shemna SS, Dubey PN. Prevalence of occupational burnout among resident doctors working in public sector hospitals in Mumbai. Indian J Community Med. 2019 Oct; 44(4): 352-6

20. Chan AOM, Huak CY. Psychological impact of the 2003 severe acute respiratory syndrome outbreak on health care workers in a medium size regional general hospital in Singapore. Occup Med. 2004; 54: 190-6

21. Peckham C. Medscape national and physician burnout and depression report 2018. 2018 [cited 2021 Aug]. Available from https://www.medscape.com/slideshow/2018-lifestyle-burnoutdepression$\underline{6009235}$

22. Cabrera MT, Enyedi LB, Ding L, Mac-Donald SM. Sexual harassment in ophtalmology: A survey study. Ophtalmology. 2019; 126(1): 172-4

23. Morgantini LA, Naha U, Wang H, Francavilla S, Acar O, Flores JM, et al. Factors contributing to healthcare professional burnout during the Covid-19 pandemic: A rapid turnaround global survey. PLoS ONE. 2020; 15(9): 1-11 